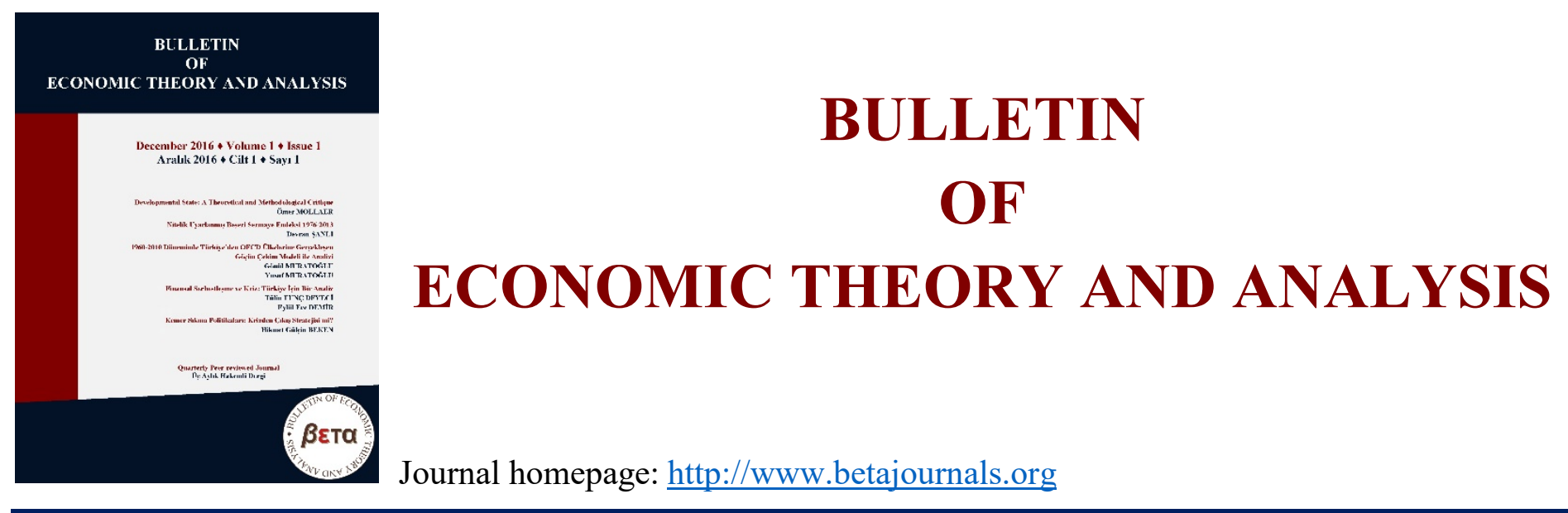

\title{
The Impact of Domestic Investment on Economic Growth: New Policy Analysis from Algeria
}

Sayef Bakari

To cite this article: Bakari, S. (2018). The Impact of Domestic Investment on Economic Growth: New Policy Analysis from Algeria. Bulletin of Economic Theory and Analysis, 3(1), 35-51.

Received: 9 Sep 2017

Accepted: 26 Sep 2018

Published online: 30 Sep 2018

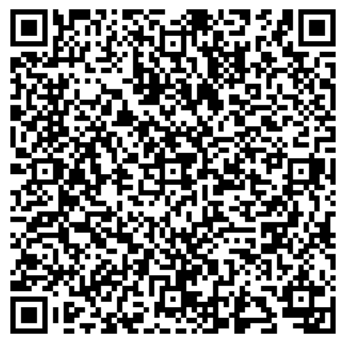




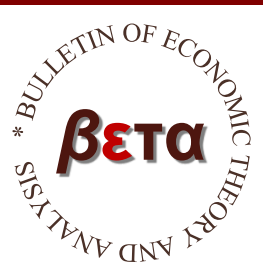

\title{
Bulletin of Economic Theory and Analysis
}

Volume III, Issue 1, pp. 35-51, 2018

http://www.betajournals.org

\section{The Impact of Domestic Investment on Economic Growth: New Policy Analysis from Algeria}

\author{
Sayef BAKARI ${ }^{\mathrm{a}}$ \\ a Department of Economics Science, LIEI, Faculty of Economic Sciences and Management of \\ Tunis (FSEGT), University Of Tunis El Manar, TUNISIA
}

\begin{abstract}
This paper investigates the relationship between domestic investment and economic growth in Algeria. In order to achieve this purpose, annual data for the period between 1969 and 2015 was tested by using co integration analysis of Vector Error Correction Model. The equation of the long run relationship shows that domestic investment has a negative effect on economic growth. However, in the short run term, the Granger Causality Tests shows that domestic investment cause economic growth in Algeria. These results prove that domestic investment is a source of economic growth for Algeria, but unfortunately it suffers from several obstacles and problems that are directly related to the poor management and the weak strategy for development and investment, Lead to the appearance of this long-term negative effect, if it left in this situation.

Keywords

Domestic

Investment, VECM, Causality, Economic Growth, Algeria

JEL Classification C13, E22, F14
\end{abstract}

CONTACT Sayef BAKARI, $\bowtie$ bakari.sayef@yahoo.fr $\risingdotseq$ Department of Economics Science, LIEI, Faculty of Economic Sciences and Management of Tunis (FSEGT), University Of Tunis El Manar, TUNISIA 


\section{Introduction}

In 1993, Algeria underwent a period of transition, from a centralized socialist approach to a market economy. In this manner, her natural resources played the most important role. Algeria has Africa's fourth-largest economy. Algeria's national income is estimated at more than \$211.9 billion in 2014, with GDP growing 4 percent from last year. Socialism also played its role in disrupting the agricultural role, headed towards the industrial sector without ruddiness, but the arrival of President Chazli Bennid confirmed the importance of changing the old policy as a whole. The events of Black October in 1988 were behind the acceleration of the reform process. Political and Economic Reforms during the President's period, the world oil price slump in 1986 was behind the country's crisis at the time. The oil sector is the mainstay of the Algerian economy, accounting for about $60 \%$ of the general budget, $30 \%$ of GDP and $97 \%$ of total exports. Algeria aspires to reduce the dependence on oil revenues by focusing on agriculture to limit the import of agricultural products such as cereals, potatoes and fruits in particular. And the development of export of other products such as dates, which is famous for. Algeria also has other natural resources such as iron, coal and uranium. The main objective of the reforms, the transformation of the market economy, was to seek investment and create a competitive environment within the country. The State left the administration in public institutions by $2 / 3$ and abolished its monopoly on imports. Finally, it frequently encouraged the privatization of the agricultural sector. Algeria's economic indicators rose in the second half of the 1990s due to the World Bank's support for reform policies and the debt rescheduling1 process approved by the Paris Club2. Although Algeria's ranking in terms of GDP is 49 out of the 190 countries surveyed, its unemployment rate is relatively high at $9.8 \%$ according to 2013 statistics.

\footnotetext{
${ }^{1}$ Debt restructuring is a process that allows a private or public company, or a sovereign entity facing cash flow problems and financial distress to reduce and renegotiate its delinquent debts to improve or restore liquidity so that it can continue its operations.

2 The Paris Club is a group of officials from major creditor countries whose role is to find coordinated and sustainable solutions to the payment difficulties experienced by debtor countries. As debtor countries undertake reforms to stabilize and restore their macroeconomic and financial situation, Paris Club creditors provide an appropriate debt treatment. Paris Club creditors provide debt treatments to debtor countries in the form of rescheduling, which is debt relief by postponement or, in the case of concessional rescheduling, reduction in debt service obligations during a defined period (flow treatment) or as of a set date (stock treatment).
} 
Given the dire economic situation in which Algeria is confronted, it is clear to us that domestic investment is one of the most necessary solutions to promote the advancement of the country and reduce most of these disasters. Domestic investment occupies a very important place in the economies of the countries as it stimulates economic growth and sustainable development through its impact on several economic variables. Romer (1986); Lucas (1988); Grier and Tullock (1989); Barro (1991); Levine and Renelt (1991) Mankiw, Romer and Weil (1992); Fischer (1993) confirmed the importance of domestic investment in improving economic growth. Other studies show that domestic investment does not necessarily have an influence or a favorable effect on economic growth Khan (1996); Devarajan (1996).

In particular, this work tries to empirically find an answer for the question of whether there is a nexus between domestic investment and economic growth in Algeria, to achieve this objective the paper is structured as follows. In section 2, we present the review literature concerning the nexus between domestic investment and economic growth. Secondly, we discuss the Methodology Model Specification and data used in this study in Section 3. Thirdly, Section 4 presents the empirical results as well as the analysis of the findings. Finally, Section 5 is dedicated to our conclusion.

\section{Literature Survey}

Several empirical studies which investigated the relationship between domestic investment and economic growth found several different results that describe this relationship. These studies include: 


\section{Table 1}

Studies related to the relationship between domestic investment and economic growth

\begin{tabular}{|c|c|c|c|c|c|}
\hline & Authors & Countries & Period & Methodology & Results \\
\hline 1 & Omri and Kahouli (2014) & 13 MENA countries & $1990-2010$ & GMM & $\mathrm{DI}<=>\mathrm{Y}$ \\
\hline 2 & Farhani et al (2014) & France & $1970-2010$ & $\begin{array}{l}\text { Cointegration Analysis } \\
\text { ARDL } \\
\text { VECM } \\
\text { Granger Causality Test }\end{array}$ & $\begin{array}{l}\mathrm{DI}<=>\text { Y: LR } \\
\mathrm{DI}<=>\text { Y: SR }\end{array}$ \\
\hline 3 & Forgha et al (2014) & Cameroun & $1980-2013$ & 2SLS & $\mathrm{DI}=>\mathrm{Y}$ \\
\hline 4 & Bayar (2014) & $\begin{array}{l}7 \text { emerging countries } \\
\text { in Asia }\end{array}$ & $1982-2012$ & $\begin{array}{l}\text { Cointegration Analysis } \\
\text { Granger Causality Test }\end{array}$ & $\mathrm{DI}<=>$ Y \\
\hline 5 & Adams and Opoku (2015) & 22 SSA Countries & $1980-2011$ & GMM & $\mathrm{DI}=>\mathrm{Y}$ \\
\hline 6 & Tahir \& Azid (2015) & 50 Developing Countries & $1990-2009$ & $\begin{array}{l}\text { Fixed Effects } \\
\text { Random Effects } \\
\text { Pooled OLS } \\
\text { 2SLS }\end{array}$ & $\mathrm{DI}=>\mathrm{Y}$ \\
\hline 7 & Tang and Tan (2015) & Malaysia & $1991-2010$ & $\begin{array}{l}\text { Cointegration Analysis } \\
\text { ARDL } \\
\text { VAR } \\
\text { Granger Causality Test }\end{array}$ & $\mathrm{DI}<=>\mathrm{Y}$ \\
\hline 8 & Bakari (2017a) & Sudan & $1976-2015$ & $\begin{array}{l}\text { Cointegration Analysis } \\
\text { ECM } \\
\text { Granger Causality Test }\end{array}$ & $\begin{array}{l}\text { DI \# Y: LR } \\
\text { DI <= Y: SR }\end{array}$ \\
\hline 9 & Bakari (2017b) & Gabon & $1980-2015$ & $\begin{array}{l}\text { Cointegration Analysis } \\
\text { ECM } \\
\text { Granger Causality Test }\end{array}$ & $\begin{array}{l}\mathrm{DI}=>\mathrm{Y}: \mathrm{LR}(-) \\
\mathrm{DI}=>\mathrm{Y}: \mathrm{SR}\end{array}$ \\
\hline 10 & Bakari (2017c) & Malaysia & $1960-2015$ & $\begin{array}{l}\text { Correlation Analysis } \\
\text { Cointegration Analysis } \\
\text { ECM } \\
\text { Granger Causality Test }\end{array}$ & $\begin{array}{l}\text { DI => Y: LR } \\
\text { DI \# Y:SR }\end{array}$ \\
\hline 11 & Sapkota and Bastola (2017) & $\begin{array}{l}14 \text { Latin American } \\
\text { Countries }\end{array}$ & $1980-2010$ & $\begin{array}{l}\text { OLS } \\
\text { Fxed Effects Models } \\
\text { Random Effects Models } \\
\text { Hausman Test }\end{array}$ & DI \# Y \\
\hline 12 & Keho (2017) & Cote D'Ivoire & $1965-2014$ & $\begin{array}{l}\text { ARDL } \\
\text { Granger Causality Test }\end{array}$ & $\begin{array}{l}\mathrm{DI}<=>\mathrm{Y}: \mathrm{LR} \\
\mathrm{DI}<=>\mathrm{Y}: \mathrm{SR}\end{array}$ \\
\hline 13 & Alagidede and Ibrahim (2017) & Ghana & $1980-2013$ & GMM & DI \# Y \\
\hline 14 & Menegaki and Tugcu (2017) & G7 countries & $1995-2013$ & $\begin{array}{l}\text { ARDL } \\
\text { Granger Causality Test }\end{array}$ & $\begin{array}{l}\mathrm{DI}=>\mathrm{Y}: \mathrm{LR} \\
\mathrm{DI}=>\mathrm{Y}: \mathrm{SR}\end{array}$ \\
\hline 15 & Choi and Yi (2017) & 105 Countries & $1994-2014$ & $\begin{array}{l}\text { Fixed Effects Models } \\
\text { Random Effects Models } \\
\text { Pooled OLS }\end{array}$ & $\mathrm{DI}=>\mathrm{Y}$ \\
\hline 16 & Sarwar et al (2017) & 210 Countries & $1960-2014$ & $\begin{array}{l}\text { Cointegration Analysis } \\
\text { FMOLS } \\
\text { VECM } \\
\text { Granger Causality Test }\end{array}$ & $\begin{array}{l}\mathrm{DI}<=\text { Y: LR } \\
\mathrm{DI}<=>\mathrm{Y}: \mathrm{SR}\end{array}$ \\
\hline 17 & Khobai et al (2017) & South Africa & $1985-2014$ & $\begin{array}{l}\text { Cointegration Analysis } \\
\text { ARDL }\end{array}$ & $\begin{array}{l}\text { DI => Y: LR } \\
\text { DI \# Y: SR }\end{array}$ \\
\hline 18 & Jibiry and Abdu (2017) & Nigeria & $1970-2014$ & $\begin{array}{l}\text { Cointegration Analysis } \\
\text { VECM } \\
\text { Granger Causality Test }\end{array}$ & $\begin{array}{l}\text { DI \# Y: LR } \\
\text { DI <= Y: SR }\end{array}$ \\
\hline 19 & Adams et al (2017) & Senegal & $1970-2014$ & ARDL & $\mathrm{DI}=>\mathrm{Y}: \mathrm{LR}$ \\
\hline
\end{tabular}




\begin{tabular}{|c|c|c|c|c|c|}
\hline 20 & Siddique et al (2017) & Pakistan & $1975-2015$ & ARDL & DI \# Y \\
\hline 21 & Bano et al (2017) & 180 countries & $1981-2012$ & $\begin{array}{l}\text { OLS } \\
\text { Hausman Test }\end{array}$ & $\mathrm{DI}=>\mathrm{Y}$ \\
\hline 22 & Mbulawa (2017) & Botswana & $1985-2015$ & $\begin{array}{l}\text { OLS } \\
\text { VECM }\end{array}$ & $\mathrm{DI}=>\mathrm{Y}$ \\
\hline 23 & Bakari and Mabrouki (2017) & $\begin{array}{l}\text { South-Eastern } \\
\text { Europe Countries }\end{array}$ & $2006-2016$ & $\begin{array}{l}\text { Fixed Effect Model } \\
\text { Random Effects Models } \\
\text { Hausman Test }\end{array}$ & $\mathrm{DI}=>\mathrm{Y}$ \\
\hline 24 & Huchet-Bourdon (2018) & 196 countries & $1988-2014$ & GMM & $\mathrm{DI}=>\mathrm{Y}$ \\
\hline 25 & Bakari and Ahmadi (2018) & South Africa & $1960-2015$ & $\begin{array}{l}\text { Cointegration Analysis } \\
\text { ECM }\end{array}$ & $\begin{array}{l}\text { DI => Y : LR } \\
\text { DI \# Y: SR }\end{array}$ \\
\hline 26 & Umar-Gingo et Demireli (2018) & Ghana & $1980-2015$ & $\begin{array}{l}\text { Cointegration Analysis } \\
\text { VECM }\end{array}$ & $\begin{array}{l}\text { DI => Y: LR (-) } \\
\text { DI \# Y: SR }\end{array}$ \\
\hline 27 & Sepehrdoust (2018) & 14 OPEC Countries & $2002-2015$ & GMM & DI \# Y \\
\hline 28 & Karimi et Daiari (2018) & 10 ASEAN Countries & $1996-2014$ & $\begin{array}{l}\text { GMM } \\
\text { Fixed Effects Panel }\end{array}$ & $\mathrm{DI}=>\mathrm{Y}$ \\
\hline 29 & Golitsis et al (2018) & Albania & $1996-2014$ & $\begin{array}{l}\text { Cointegration Analysis } \\
\text { VECM } \\
\text { Granger Causality Test }\end{array}$ & DI \# Y \\
\hline 30 & Appiah (2018) & Ghana & 1960 to 2015 & $\begin{array}{l}\text { Cointegration Analysis } \\
\text { ARDL } \\
\text { ECM }\end{array}$ & DI \# Y \\
\hline
\end{tabular}

Note: DI means Domestic Investment, Y means Economic Growth, LR means Long Run, SR means Short Run, $(+)$ means Positive Effect and (-) means Negative Effect.

\section{Data and Methodology}

The analysis used in this study cover annual time series of 1969 to 2015 or 46 observations which should be sufficient to capture the relation between Export, Import, Fixed Formation Capital and economic growth in Algeria. The data set consists of observation for GDP, exports of goods and services (constant US\$), imports of goods and services (constant US\$) and Gross Fixed Formation Capital (constant US\$). All data set are taken from World Development Indicators 2016.

We will use the most appropriate method which consists firstly of determining the degree of integration of each variable. If the variables are all integrated in level, we apply an estimate based on a linear regression. On the other hand, if the variables are all integrated into the first difference, our estimates are based on an estimate of the VAR model. When the variables are integrated in the first difference we will examine and determine the cointegration between the variables, if the cointegration test indicates the absence of cointegration relation, we will use the model VAR. If the cointegration test indicates the presence of a cointegration relation between the different variables studied, the model VECM will be used. 
The augmented production function including domestic investment, exports and imports is expressed as:

$$
\mathrm{GDP}_{\mathrm{t}}=\mathrm{f}(\mathrm{EX}, \mathrm{IM}, \mathrm{FBCF})
$$

The function can also be represented in a log-linear econometric format thus:

$$
\log (\mathrm{GDP})_{\mathrm{t}}=\beta_{0}+\beta_{1} \log (\mathrm{EX})_{\mathrm{t}}+\beta_{2} \log (\mathrm{IM})_{\mathrm{t}}+\beta_{3} \log (\mathrm{FBCF})_{\mathrm{t}}+\varepsilon_{\mathrm{t}}
$$

Where $\beta_{0}$ is the constant term, $\beta_{1}$ is the coefficient of variable (Exports: EX), $\beta_{2}$ is the coefficient of variables (Imports: IM), $\beta_{3}$ is coefficient of variable (Domestic Investment: FBCF), $t$ is the time trend and $\varepsilon$ is the random error term assumed to be normally, identically and independently distributed.

\section{Empirical analysis}

\subsection{Tests for unit root}

The first step is to check the variation of the variables over time to determine the links between them. To complete this step, there are certain tests that aim to determine the stationarity of the variables. In our case, we will use the most appropriate tests which are the PP test and the ADF test.

Table 2

Tests for unit root $A D F$ and $P P$

\begin{tabular}{ccccc}
\hline Unit Roots Tests & \multicolumn{2}{c}{ ADF } & \multicolumn{1}{c}{ PP } \\
\cline { 2 - 5 } & Constant & Constant, Linear Trend & Constant & Constant, Linear Trend \\
Y & $(1.790144)$ & $(1.994324)$ & $(1.885455)$ & $(2.302784)$ \\
& {$[8.798281]$} & {$[8.981170]$} & {$[8.462055]$} & {$[8.671723]$} \\
DI & $(1.497865)$ & $(1.608179)$ & $(1.537841)$ & $(2.014662)$ \\
& {$[4.485247]$} & {$[4.382049]$} & {$[4.550157]$} & {$[4.445817]$} \\
X & $(1.146073)$ & $(2.556095)$ & $(1.076945)$ & $(2.524800)$ \\
& {$[8.837526]$} & {$[8.801516]$} & {$[9.286612]$} & {$[9.429443]$} \\
M & $(1.216012)$ & $(1.366708)$ & $(1.384671)$ & $(1.596834)$ \\
& {$[5.012050]$} & {$[4.587137]$} & {$[5.060018]$} & {$[4.997977]$} \\
\hline
\end{tabular}

$* * * ; *$ and $*$ denote significances at $1 \% ; 5 \%$ and $10 \%$ levels respectively

( ) denotes stationarity in level

[ ] denotes stationarity in first difference 
The results of the two stationary tests show that all the variables are stationary and especially they are integrated in order 1 .

This step is more important and we will use a set of information criteria such as AIC and SC to determine the number of optimal delays included in our model.

Table 3

VAR Lag Order Selection Criteria

\begin{tabular}{cccllll}
\hline Lag & Log L & LR & FPE & AIC & SC & HQ \\
\hline 1 & 288.1479 & NA & $2.02 \mathrm{e}-11$ & -13.27551 & $-12.60679^{*}$ & -13.03200 \\
2 & 316.3318 & $45.36920^{*}$ & $1.14 \mathrm{e}-11^{*}$ & $-13.86984^{*}$ & -12.53242 & $-13.38283^{*}$ \\
3 & 324.3212 & 11.30217 & $1.77 \mathrm{e}-11$ & -13.47908 & -11.47295 & -12.74856 \\
4 & 340.4180 & 19.63026 & $1.95 \mathrm{e}-11$ & -13.48381 & -10.80896 & -12.50978 \\
5 & 358.5276 & 18.55125 & $2.12 \mathrm{e}-11$ & -13.58671 & -10.24316 & -12.36917 \\
\hline
\end{tabular}

* indicates lag order selected by the criterion

LR: sequential modified LR test statistic (each test at 5\% level)

FPE: Final prediction error

AIC: Akaike information criterion

SC: Schwarz information criterion

HQ: Hannan-Quinn information criterion

Based on the information criterion SC, the number of the optimal lag chosen in our model is equal to 1 .

\subsection{Cointegration analysis}

The third step in applying the Sims model is the cointegration analysis. This step consists to verify the cointegration between the variables. For this reason, we will use the Johanson test. 
Table 4

Johanson Test

\begin{tabular}{|c|c|c|c|c|}
\hline \multicolumn{5}{|c|}{ Unrestricted Cointegration Rank Test (Trace) } \\
\hline $\begin{array}{l}\text { Hypothesized No. } \\
\text { of CE(s) }\end{array}$ & Eigenvalue & Trace Statistic & $\begin{array}{c}\text { 0.05 Critical } \\
\text { Value }\end{array}$ & Prob.** \\
\hline None * & 0.723314 & 124.5746 & 47.85613 & 0.0000 \\
\hline At most $1 *$ & 0.642209 & 68.04034 & 29.79707 & 0.0000 \\
\hline At most $2 *$ & 0.364868 & 22.81687 & 15.49471 & 0.0033 \\
\hline At most 3 & 0.062598 & 2.844272 & 3.841466 & 0.0917 \\
\hline
\end{tabular}

The results of the Johanson test show that there are 3 cointegration relationships, so the error correction model will be retained. The equation of long-term equilibrium is written as follows:

$$
\log (\mathrm{GDP})=0.0212-0.0755 \log (\mathrm{FBCF})+0.2091 \log (\mathrm{EX})+0.3904 \log (\mathrm{IM})
$$

According to this equation, a $1 \%$ increase in domestic investment leads to a decrease of $0.075563 \%$ GDP. On the other hand, a 1\% increase in exports and imports leads to an increase of $0.3 \%$ and $0.2 \%$ Of GDP. To verify the credibility of this long-term equation, it is estimated using the error correction model

\subsection{Estimation of error correction model (ECM)}

In his analysis, the estimation of the error correction model has two outputs; the first is the determination of the link between variables in the long run using the Least Squares of GaussNewton. And the second is the determination of the nexus between variables in the short run using Wald Tests.

\subsubsection{Estimation of the cointegration equation: the long-run equilibrium equation}

The following table shows the results of estimating the equation. If the coefficient of the variable $\mathrm{C}(1)$ is negative and possesses a significant probability. This means that all variables in the long-term relationship are significant in explaining the dependent variables. 
Table 5

Estimation of the cointegration equation: the long-run equilibrium equation

\begin{tabular}{lllll}
\hline & Coefficient & Std. Error & t-Statistic & Prob. \\
\hline $\mathrm{C}(1)$ & -0.613394 & 0.275647 & -2.225289 & 0.0321 \\
\hline
\end{tabular}

Method: Least Squares (Gauss-Newton / Marquardt steps)

$\mathrm{D}(\mathrm{DLOG}(\mathrm{GDP}))=\mathrm{C}(1) *($ DLOG(GDP(-1) $)+0.075 * \mathrm{DLOG}(\mathrm{FBCF}(-1)) \quad-\quad 0.209 * \mathrm{DLOG}(\mathrm{EX}(-1)) \quad-$ $0.390 * \mathrm{DLOG}(\mathrm{IM}(-1))-0.021)+\mathrm{C}(2) * \mathrm{D}(\mathrm{DLOG}(\mathrm{GDP}(-1)))+\mathrm{C}(3) * \mathrm{D}(\mathrm{DLOG}(\mathrm{FBCF}(-1)))+\mathrm{C}(4) * \mathrm{D}(\mathrm{DLOG}(\mathrm{EX}(-$ $1)))+\mathrm{C}(5) * \mathrm{D}(\mathrm{DLOG}(\mathrm{IM}(-1)))+\mathrm{C}(6)$

In our case, the correction error term is significant and has a negative coefficient. These prove that in the long run, a $1 \%$ increase in domestic investment leads to a decrease of $0.075563 \%$ GDP.

\subsubsection{VEC Granger Causality/Block Exogeneity Wald Tests}

The objective of the WALD test is to determine that if there is a short-term relationship between the variables used.

Table 6

VEC Granger Causality/Block Exogeneity Wald Tests

\begin{tabular}{lccc}
\hline $\begin{array}{l}\text { Dependent variable: } \\
\text { D(DLOG(GDP)) }\end{array}$ & Chi-sq & df & Prob. \\
\hline D(DLOG(FBCF)) & 4.571326 & 1 & 0.0325 \\
D(DLOG(EX)) & 0.243886 & 1 & 0.6214 \\
D(DLOG(IM)) & 0.004297 & 1 & 0.9477 \\
\hline
\end{tabular}

The results of the Wald Test prove that domestic investments cause economic growth in the short run.

\subsubsection{Checking the quality of model}

Finally, we applied the diagnostic tests and the CUSUM test to check the robustness and the stability of our estimate and the quality of the model. 
Table 7

Diagnostics Tests

\begin{tabular}{lccc}
\hline \multicolumn{4}{c}{ Heteroskedasticity Test: Harvey } \\
\hline F-statistic & 1.135180 & Prob. F(12,31) & 0.3692 \\
Obs*R-squared & 13.43223 & Prob. Chi-Square(12) & 0.3384 \\
Scaled explained SS & 18.70070 & Prob. Chi-Square(12) & 0.0960 \\
\hline \multicolumn{4}{c}{ Heteroskedasticity Test: ARCH } \\
\hline F-statistic & 0.890714 & Prob. F(1,41) & 0.3508 \\
Obs*R-squared & 0.914301 & Prob. Chi-Square(1) & 0.3390 \\
\hline \multicolumn{4}{c}{ F-statistic } \\
Obs*R-squared & Breusch-Godfrey Serial Correlation LM Test: \\
\hline
\end{tabular}

Graph 1

Test CUSUM

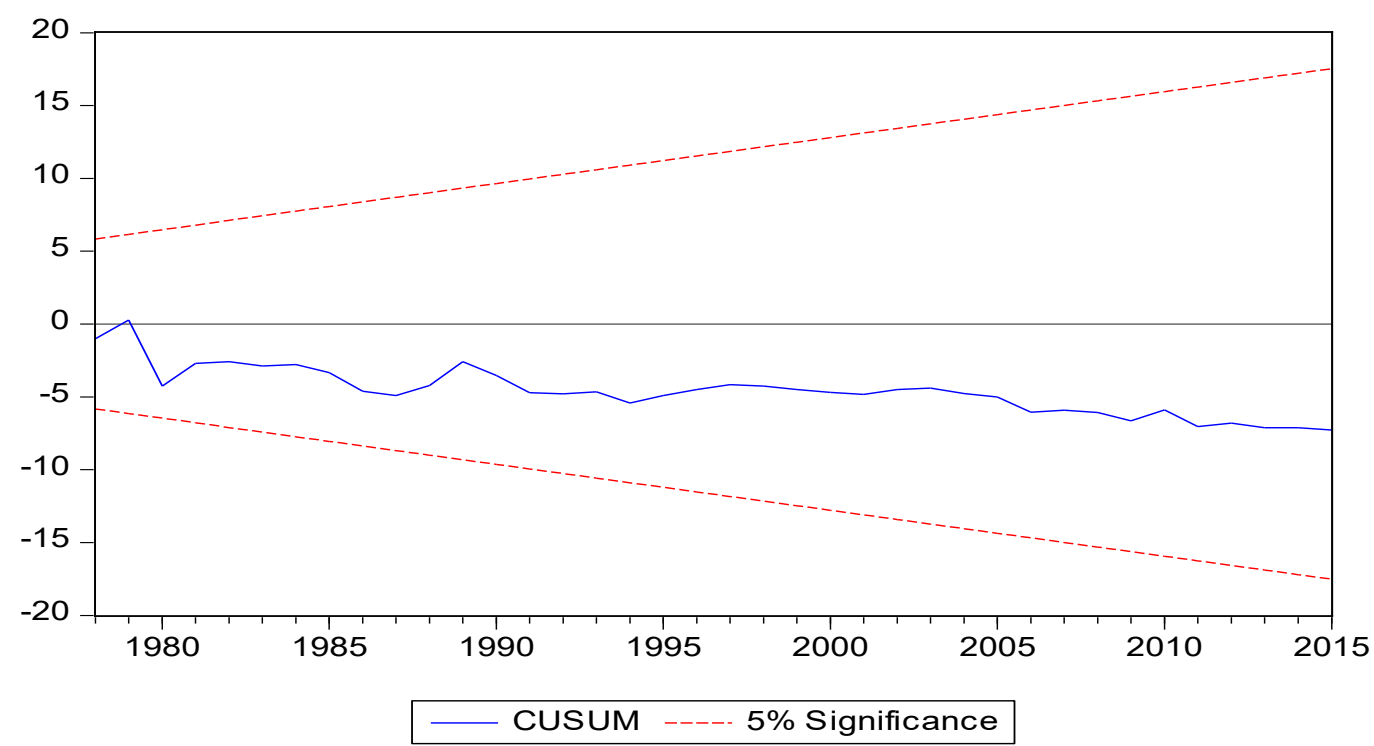

The results of verification of our empirical investigation show that our results are satisfactory and acceptable.

\section{Conclusion and Recommendations}

The aim of this study was to explain the impact of domestic investment on economic growth in Algeria during the period 1969-2015. The Co-integration, Vector Error Correction Model and Granger's Causality tests are applied to investigate the influence of exports, imports and domestic investment on economic growth. The unit root properties of the data were examined 
using the Augmented Dickey Fuller test (ADF) and the Phillips-Perron test (PP) after that the cointegration and error correction model were conducted. Empirical results show that in the long run domestic investment has a negative effect on economic growth; however, exports and imports have a positive effect on economic growth. In the short run, only domestic investment and imports cause economic growth in Algeria. These empirical results can be explained by four reasons which make domestic investment can be able to produce economic growth in Algeria.

\section{1) The First reason is the lack of a competitive market.}

This is due to the inability of the private sector to participate in the investment process. The sector has not yet reached the required level, although its activity represents $44 \%$ of the national activity. In addition, the lack of experience and experience in this sector make it not contribute as required. We also note from the Algerian economy that the commercial activity related to imports is predominant and this is because of the high profitability compared to the investment activity. In addition to the previous reasons, the decline in investments can be attributed to the large number of informal activities which represent a quarter of the economic activity. This situation does not allow any investor to invest in a market where the black market is dominant; this issue is sensitive and must be dealt with wisely because it employs 1.2 million workers3. Also, the inefficiency of the banking institutions, especially the private sector, its lack of development and the closure of some banks due to its failure to honor its commitments to the customers and the community lead Algerian investors prefer to go to other countries where the financial environment is effective and appropriate.

\section{2) The second reason is the lack of transparency in transactions related to investment.}

The existence of corrupt practices in many countries of the world is the focus of interest of investors and civil society on these practices, which aim to achieve the maximum profit in the shortest time and illegally. This can be done either by trading in arms or by trading in drugs and

\footnotetext{
${ }^{3}$ The facilitations and manipulations in this area encouraged the private to continue this activity rather than venture into the investment process.
} 
financial crimes, so those who do this are trying to carry out the subsequent process of corruption, which is money laundering so that it can be seen as a legitimate source, so they try to contact and search for the link that is achieved. They have this objective, and this is done by dealing with the bank, judges, lawyers, politicians, businessmen, police and others to achieve this goal. Therefore, the more information and transparency is clear in the transactions of these bodies, the more the reasons for making local investments. Therefore, the state should make great efforts to eliminate corruption, and this is to monitor all activities and those responsible for corruption, and this is done if there is an administrative, judicial, journalist, civil society and independent media.

\section{3) The third reason is the lack of transparency in economic policy.}

The existence of a clear economic policy will be an incentive to make investments in various fields such as, monetary policy, finance, taxation, social legislation on the conditions of employment and insurance. A government that operates in stable and clear conditions is better than governments that are characterized by volatility and a change in economic policy. The objective of the investor is to know the climate and the economic environment in which he conducts his activity. In other words, he knows the previous operations of the investment process and the following. This is because investing in fixed assets is a long-term process that can be up to 50 years. The successive governments 'credibility is a key factor in encouraging investments because the divergence and retreat from the previous economic policies of Algeria has affected its credibility and this has made the investor in a volatile and unstable situation in the event of fear of future governments' retreat on agreed agreements and laws. For example, in the area of privatization, the lack of clear information and laws encourage the investor to refrain from entering this activity, and the change of laws at random and without justification is an indicator of the instability of the economic system, and the transparency of financial transactions is an incentive to Investment.

\section{4) The last reason is the weakness of the agricultural sector}

Algeria now ranks first in the list of countries importing food and agricultural products with a population of more than 30 million and an average bill of 2.5 billion dollars annually. This 
is due to the poor profitability of agricultural investments, as well as the lack of exploitation of agricultural resources, Weak technology, and on the whole they reveal this deep crisis in the agriculture sector. The irrigation system and waterways are often in poor condition, despite efforts to fight land salinity like other Maghreb countries, and Algeria is still suffering from the problem of soil erosion, which is a major hindrance to the future of natural resources in the country. In addition, desertification threatens 32 million hectares of vast land and forest cover in northern Algeria, noting that the intensive exploitation of groundwater resources has reduced its capacity, while poor quality land has endured in the last 10 years attacks from the human population and agricultural techniques that do not it fits the impact on some ecosystems.

In summary, domestic investments are a source of economic growth in Algeria (because domestic investments cause economic growth in the short term) but in their current situation they are not able to stimulate economic growth and they will lead the country to a bigger bankruptcy (because domestic investments have a negative impact on long-term economic growth). This makes it imperative for the Algerian government to do as soon as possible encouraging investments; Improving laws and economic strategies: resistance to corruption and bribery; attention to the agricultural sector; and establishing a policy of economic diversification 


\section{References}

Adams, S., Klobodu, E. K. M., \& Lamptey, R. O. (2017). The effects of capital flows on economic growth in Senegal. The Journal of Applied Economic Research, 11(2), 1-22.

Adams, S., \& Opoku, E. E. O. (2015). Foreign direct investment, regulations and growth in subSaharan Africa. Economic Analysis and Policy, Manuscript submitted for publication, http://dx.doi.org/10.1016/j.eap.2015.07.001.

Alagidede, P., \& Ibrahim, M. (2016). On the causes and effects of exchange rate volatility on economic growth: Evidence from Ghana. Journal of African Business, 18(2), 169-193.

Appiah, M. O. (2018). Investigating the multivariate Granger causality between energy consumption, economic growth and CO2 emissions in Ghana. Energy Policy, 112, 198208.

Bakari, S. (2017a). Appraisal of trade: Potency on economic growth in Sudan: New empirical and policy analysis. Asian Development Policy Review, 5(4), 213-225.

Bakari, S. (2017b). The Impact of domestic investment on economic growth: New evidence from Malaysia. Journal of Smart Economic Growth, 2(2), 105- 121.

Bakari, S. (2017c). The long run and short run impacts of exports on economic growth: Evidence from Gabon. The Economic Research Guardian. 7(1), 40-57.

Bakari, S., \& Ahmadi, A. (2018). Why is South Africa still a developing country?..International Academic Journal of Economics, 5(2), 2018, 1-19.

Bakari, S. \& Mabrouki, M. (2017). The effect of agricultural exports on economic growth in South-Eastern Europe: An empirical investigation using panel data. Journal of Smart Economic Growth, MPRA Working Paper.

Barro, R. J. (1991). Economic growth in a cross section of countries. Quarterly Journal of Economics, 106, 407-444.

Bayar, Y. (2014). Savings, foreign direct investment inflows and economic growth in emerging Asian. Asian Economic and Financial Review, 4(8), 1106-1122.

Bano, S., Ahmed, A., Zhao, Y., \& Ejaz, H. (2017). The effect of human capital accumulation on economic growth. International Journal of Economics and Empirical Research. 5 (2), 6172 .

Choi, C., \& Yi, M. H. (2017). The internet, R\&D expenditure and economic growth. Applied Economics Letters, 25(4), 264-267. http://dx.doi.org/10.1080/13504851.2017.1316819 
Devarajan, S., Swaroop, V., \& Heng-fu, Z. (1996). The composition of public expenditure and economic growth. Journal of Monetary Economics, 37, 313-344.

Dickey, D. A., \& Fuller, W. A. (1979). Distribution of estimators of autoregressive time series with a unit root. Journal of the American Statistical Association, 74, 427-31.

Dickey, D. A., \& Fuller, W. A. (1981). Likelihood ratio statistics for autoregressive time series with a unit root. Econometrica, 49(4), 1057-72.

Farhani, S., Shahbaz, M., \& Rahman, M. (2014). Natural gas consumption and economic growth in France: Evidence for the role of exports, capital and labor. Business School, Working Paper.

Fischer, S. (1993). The role of macroeconomic factors in growth. National Bureau of Economic Research Working Paper No. 4565.

Forgha, N. G., \& Mbella, M. E. (2014). External debt, domestic investment and economic growth in Cameroon: A system estimation approach. Journal of Economics Bibliography, 1(1), 316.

Gingo, H. U., \& Demireli, E. (2018). Analysis of the effect of foreign direct investment on economic growth: The case of Ghana. International Journal of Contemporary Economics and Administrative Sciences, 7(34), 119-138.

Grier, K., \& Tullock, G. (1989). An empirical analysis of cross-national economic growth: 19511980. Journal of Monetary Economics, 24(2), 259-276.

Golitsis,P., Avdiu, K., \& Szamosi, L. T. (2018). Remittances and FDI effects on economic growth: A VECM and GIRFs for the case of Albania. Journal of East-West Business, 124. https://doi.org/10.1080/10669868.2018.1435432

Huchet-Bourdon, M., Le Mouël, C., \& Vijil, M. (2018). The relationship between trade openness and economic growth: some new insights on the openness measurement issue. The World Economy, 41(1), 59-76.

Jibir, A., \& Abdu, M. (2017). Foreign direct investment- growth nexus: The case of Nigeria. European Scientific Journal, 13(1), 304-318.

Johansen, S. (1988). Statistical analysis of cointegration vectors. Journal of Economic Dynamics and Control, 12(2-3), $231-254$.

Johansen, S. (1991). Estimation and hypothesis testing of cointegration vectors in gaussian vector autoregressive models. Econometrica, 59, 1551-1580. 
Johansen, S., \& Juselius, K. (1990). Maximum likelihood estimation and inference on cointegration, with applications to the demand for money. Oxford Bulletin of Economics and Statistics, 52, 169-210.

Karimi, M. S., \& Heshmati Daiari, E. (2018). Does institutions matter for economic development? Evidence for ASEAN selected countries. Iranian Economic Review, 22(1), $1-20$.

Keho, Y. (2017). The exports and economic growth nexus in Cote D'ivoire: Evidence from a multivariate time series analysis. Asian Journal of Economic Modelling, 5(2), 135-146.

Khan, M. S. (1996). Government investment and economic growth in the developing world. The Pakistan Development Review, 35, 419-439.

Khobail, H., Mugano, G., \& Le Roux, P. (2017). The impact of electricity price on economic growth in South Africa. International Journal of Energy Economics and Policy, 7(1), $108-116$.

Levine, R., \& Renelt, D. (1991). Cross-country studies of growth and policy. World Bank Working Paper No 608.

Lucas, R. E. (1988). On the mechanisms of economic development. Journal of Monetary Economics, 22, 3-42.

Mankiw, G. N., Romer, D., \& Weil, D. (1992). A contribution to the empirics of economic growth. Quarterly Journal of Economics, 107(2), 407-437.

Mbulawa, S. (2017). The impact of economic infrastructure on long term economic growth in Botswana. Journal of Smart Economic Growth, 2(1), 15-33.

Omri, A., \& Kahouli, B. (2014). The nexus between foreign investment, domestic capital and economic growth: empirical evidence from the MENA region. Research in Economics, $68,257-263$.

Phillips, P. C. B., \& Perron, P. (1988). Testing for a unit root in time series regression. Biometrika, 75(2), 335-46.

Romer, P. M. (1986). Increasing return and long run growth. Journal of Political Economy, 95, 1002-1037.

Sapkota, P., \& Bastola, U. (2017). Foreign direct investment, income, and environmental pollution in developing countries: Panel data analysis of Latin America. Energy Economics. 64, 206-212. 
Sarwar, S., Chen, W., \& Waheed, R. (2017). Electricity consumption, oil price and economic growth: Global prespective. Renewable and Sustainable Energy Reviews. 76, 9-18.

Sepehrdoust, H. (2018). Impact of information and communication technology and financial development on economic growth of OPEC developing economies. Kasetsart Journal of Social Sciences, Manuscript submitted for publication. https://doi.org/10.1016/j.kjss.2018.01.008.

Siddique, H. M. A., Ullah, K., \& Haq, I. U. (2017). External debt and economic growth nexus in Pakistan. International Journal of Economics and Empirical Research, 5(2), 73-77.

Sims, C. A. (1980). Macroeconomics and Reality. Econometrica, 48(1), 1-48.

Tang, C. F., \& Tan, E. C. (2015). The relative contributions of domestic and foreign direct investments and exports to Malaysia's economic growth. Singapore Economic Review, 60(2), 1-20.

Tahir, M., \& Azid, M. (2015). The relationship between international trade openness and economic growth in the developing economies: some new dimensions. Journal of Chinese Economic and Foreign Trade Studies, 8(2), 123-139. http://dx.doi.org/10.1108/JCEFTS02-2015-0004. 